\title{
Under the Volcano eserinin Türkçe çevirilerine bilişsel biçembilim ışı̆̆ında bir bakış
}

\section{Hilal ERKAZANCI DURMUŞ1}

\begin{abstract}
APA: Erkazancı Durmuş, H. (2020). Under the Volcano eserinin Türkçe çevirilerine bilişsel biçembilim ıșı̆ı̆ında bir bakıș. RumeliDE Dil ve Edebiyat Araştırmaları Dergisi, (20), 756-773. DOI: $10.29000 /$ rumelide.792483.
\end{abstract}

\section{$\ddot{O} \mathbf{z}$}

$\mathrm{Bu}$ çalışmanın amacı, Malcolm Lowry'nin Under the Volcano adlı romanına damga vuran ve Konsolos olarak anılan başkarakterin zihinsel biçeminin 1974 ve 1989 yıllarında yapılan iki Türçe çeviriye nasıl aktarıldığını incelemektir. Bu nedenle, çalışmada, yazın metinlerindeki dil kullanımlarını bilişsel süreçlerin ışı̆̆ında ele alan bilişsel biçembilim temel alınarak, zihinsel biçem kavramının çeviribilim için önemi vurgulanmaktadır. Bu bağlamda, başkarakterin zihinsel biçemini öne çlkaran diyaloglar ve serbest dolaylı anlatımların roman ve çevirilerde incelenmesi ile birlikte, çevirilerde yapılan biçemsel tercihlere ışık tutulmaktadır. Çalışmada, ayrıca, incelenen eserin modernist roman özelliklerini taşıması nedeniyle, çevirilerin yapıldığı yıllarda Türk yazın dizgesinde modernist roman türünün durumu mercek altına alınmaktadır. Sonuç olarak, iki çeviride de birbirinden farklı düzeylerde de olsa- kaynak metnin biçemsel özelliklerinin gözetildiği, ancak başkahramanın zihinsel biçeminden kaynaklanan anlatım bozukluklarının ve anlam bütünlüğünü bozan ifadelerin erek metnin okunabilirliğini tümüyle olumsuz etkilediği durumlarda düzeltildiği gözlemlenmiştir.

Anahtar kelimeler: Bilişsel biçembilim, zihinsel biçem, modernist roman, Türk yazın dizgesi

\section{A cognitive stylistic analysis of the Turkish translations of Under the Volcano}

\begin{abstract}
This study seeks to analyze the mind style of the protagonist Consul in the two Turkish translations of Malcolm Lowry's Under the Volcano, carried out in 1974 and 1989, respectively. Emphasizing the importance of cognitive stylistics for translation studies, the study scrutinizes the free indirech speech and dialogues that mirror the protagonist's mind style in the Turkish translations. Given that Under the Volcano is a modernist novel, the study also sheds light on the position of the modernist novel in the Turkish literary sytem, considering the period in which the two translations were released. Ultimately, the study highlights that the two translations attempt to reproduce the protagonist's mind style through differing lexical and syntactic strategies. The study also finds that the translations, albeit to varying degrees, tend to smooth out the stylistic features that totaly disrupt the reading process and deviate from the Turkish grammatical structure.
\end{abstract}

Keywords: Cognitive stylistics, mind style, modernist novel, Turkish literary system

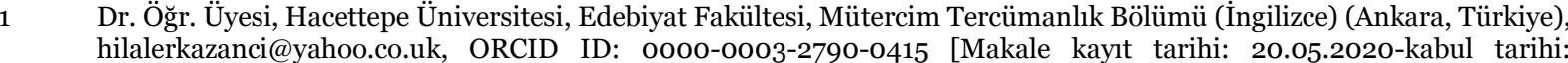
20.09.2020; DOI: 10.29000/rumelide.792483] 


\section{Giriș}

Malcolm Lowry tarafından 1945 yılında kaleme alınan Under the Volcano adlı roman, Meksika'nın eski İngiltere Konsolosu Geoffrey Firmin'in Ölüler Günü festivalinde küçük bir Meksika şehri olan Quauhnahuac'ta geçirdiği bir günü konu alır. Roman 1938'de İngiltere ile Meksika arasında çıan anlaşmazlığın bir sonucu olarak işini kaybeden ve topluma karşı gitgide yabancılaşan Konsolos Firmin, Konsolos'un eski eşi Yvonne ve kardeşi Hugh arasında geçen olayları temel almaktadır. Roman, yazıldığı dönemin Meksika'sına siyasi bir eleştiri getirerek, Konsolos'un alkolizm nedeniyle yaşadığı buhranla birlikte, İkinci Dünya Savaşı’nın neden olduğu yıkımın sonrasında insanların sanki derin bir sarhoşluk içindeymiş gibi davranmasını konu edinir. Romanda, Konsolos'un iç dünyasında yaşadığı "cehennemi" alkolün etkisi altında nasıl dile getirdiği gözler önüne serilmektedir (Lowry, 2012, s. 22).

Bazı eleştirmenler Lowry'nin romanını "başlı başına sarhoşluğu konu alan bir kitap" olarak nitelendirse de, "alkolün etkisi altındaki bir zihnin" ele alınış ve dile yansıtılış şekli Lowry'nin romanını "nevi şahsına münhasır” bir yazın eseri haline getirmektedir (Robinson, 2018, s. 1). Bu nedenle, roman 1998 yllında Modern Library tarafından yirminci yüzyılın en iyi yüz romanı içinde on birinci sıraya yerleştirilmiştir. Şeyda İnceoğlu, romanın “otobiyografik bir roman olarak mitolojik, psikolojik, sosyolojik, postkolonyal, politik ve metinlerarası açılardan ayrı ayrı incelenebilece[ğini]” belirtmiştir (2012, s. 13). Bu alanlara ek olarak, başkarakterin alkol sorununun roman boyunca dil kullanımını etkilemesi nedeniyle, romanın bilişsel biçembilim ve çevribilim ilişkisi açısından da verimli bir çalışma konusu teşkil ettiğini belirtmek gerekir. Başkarakterin zihinsel biçeminin incelenmesi, bilişsel düzeyi alkolizmden etkilenen bir kişinin dil kullanımının mercek altına alınmasını zorunlu kılmaktadır (Rundquist, 2020, s. 2).

Bilişsel biçembilim, dil düzeyinde yapılan seçimleri sistematik olarak bilişsel süreç ve yapılara bağlayan dilbilimsel incelemeleri ele almaktadır (Semino \& Culpeper, 2002, s. ix). Bilişsel biçembilimin temel araştırma konusu olan zihinsel biçem "zihinsel benliğin dilsel yansıması" olarak tanımlanmaktadır (Fowler, 1977, s. 103). Bu yüzden, belirli bir zihinsel biçem ile ön plana çıkan bir yazın eserinin çevirisinde yapılacak biçembilimsel bir inceleme büyük önem taşımaktadır. Çevirmenler bir yazın eserini çevirebilmek için kaynak metinde sistematik olarak ön plana çıan biçemsel özellikleri birer "iletişimsel ipucu" olarak kabul eder ve bu ipuçlarının kaynak metinde oluşturduğunu "varsaydıkları" etkinin ışığında erek metinde benzer etkiler oluşturabilecek biçemsel unsurlar kullanırlar (Boase-Beier, 2014, s.22). Bilişsel biçembilimin çeviribilim için önemi, bilişsel biçembilim ışığında yapılan incelemelerin çevirmenlere kaynak metinde var olduğu düşünülen bilişsel etkiye ilişkin somut "kanıtlar" sunmasından kaynaklanmaktadır (Boase-Beier, 2014). Biçembilimsel bir incelemenin yapılmaması durumunda, çevirmenler kaynak metni şekillendiren biçemsel tercihleri sadece önsezilerine ve hislerine dayanarak açıklamak zorunda kalabilir.

Diğer yandan, biçembilimin ışığında incelemeler yaparak kaynak metindeki zihinsel biçemi şekillendiren ipuçlarının farkına varan her çevirmen, bu tür biçemsel ipuçlarının tümünü çevirisine yansitamayabilir. Örneğin, Faulkner'ın (1987) The Sound and the Fury (Ses ve Öfke) eserindeki Benjy adlı karakterin sinestezik algı şeklinin 1965 yılında yapılan Türkçe çevirideki dil kullanımına nasıl yansıdığının incelendiği bir çalışmada, Türk yazın dizgesinde modernist romanın biçemsel özelliklerinin Batı tarzı modernist romanlarda görüldüğü şekliyle henüz ortaya çıkmaması ve erek okurun bahsi geçen dönemde bu tür biçemsel özelliklere yabancı olması nedeniyle, Benjy'nin zihinsel rahatsızlı̆ından kaynaklanan birçok anlatım bozuklukluğunun erek metinde düzeltildiği ve erek metne aktarılan bazı anlatım bozuklukları için hataların çevirmenden kaynaklanmadığına dair bir önsöz yazıldığı belirtilmiştir (bkz. Erkazancı Durmuş, 2018). 
$\mathrm{Bu}$ çalışmanın inceleme konusunu oluşturan Under the Volcano da modernist roman niteliği taşımaktadır (bkz. Rundquist, 2020). Modernist romanın en belirgin özelliği, belirli dil normlarından sapmaları bünyesinde barındırması nedeniyle bozulan anlam ve yapı bütünlüğünün akıcı bir okuma sürecini etkilemesidir (Daniel, 1997, s.217). Modernist romanlarda karakterin psikolojik durumunu metne yansıtan bilinç akışı tekniği yoğun olarak kullanılmaktadır (Lane \& Mota, 2016, s. 6). Modernist romanın en karakteristik özelliklerinden biri de yoğun bir şekilde sembolizme ve metinlerarasılığa dayanmasıdır (Rundquist, 2020, s. 2). Modernist romanlar olay örgüsünün karmaşıklığından çok, karakterlere ait diyalogların detaylı bir şekilde sunulması ve karakterlerin psikolojik deneyimlerinin gerçekçi bir şekilde gözler önüne serilmesi ile diğer roman türlerinden ayrılmaktadır (Rundquist, 2020, s. 2).

Modernist romanın ülkemizdeki gelişimine bakacak olursak, Türkiye'de modernizm “1930'lardan sonra egemen ideoloji olarak edebiyatımızın ana akımını oluştur[muştur]” (Gümüş, 2015, s. 57); ve modernist roman ülkemizde "yazınsal bir gerçek olarak ancak 1970'lerden sonra fark edilmeye, 1980'lerden sonra anlaşılmaya başla[mıştır]” (Gümüss, 2015, s. 57). Aynı bağlamda Yıldız Ecevit tarafından da belirtildiği gibi, biçemsel özellikleriyle ön plana çıan modernist metinler uzun bir süre Türk yazın dizgesinde yer alamamıştır (2001, s. 84). Modernist romanın bazı özelliklerini, her ne kadar Halit Ziya Uşaklıgil’in "bireysel iç yolculukları" temel alan Aşk-ı Memnu romanı, Ahmet Hamdi Tanpınar'ın "öznel zaman kavramı[na]" dayanan Saatleri Ayarlama Enstitüsü ve Atilla İlhan’ın “flash back tekniğiyle” yazdığı romanları ile bağdaştırmaya çalışsak da, Oğuz Atay'ın Tutunamayanlar'ı gibi yetmişli yıllarda "uç verme[ye]" başlayan modernist roman ve bu roman türüne özgü deneysel biçem ancak 1980 yılından sonra artan "biçimci eğilimlerin" etkisi ile Türk yazın dizgesinde yer almaya başlamıştır (Ecevit, 2001, s. 85). Modernist roman "alışılmış tüm ölçütleri tersyüz eden devrimci yapıda bir gelişmedir" ve bu nedenle modernist yazarın metni "deneysel biçimciliğin oyun alanına dönüşür" (Ecevit, 2001, s. 42). İlerleyen dönemlerde Orhan Pamuk ve Murathan Mungan gibi yazarlar geleneksel yazım tekniklerini bir kenara bırakarak, "egemen anlayışın dışında yeni arayışlar ve yenilikçi, deneysel biçimler içinde kendilerini gerçekleştirme” yolunu seçmiştir (Gümüş, 2010, s. 95).

$\mathrm{Bu}$ bağlamda, modernist romana özgü biçemsel özelliklerin henüz tam anlamıla Türk edebiyat dizgesinde yer edinemediği bir dönemde, Lowry'nin modernist romanının 1974 yll çevirisinde biçemin erek metne nasıl aktarıldığının incelenmesi önem taşımaktadır. Bu çalışma, Under the Volcano romanının 1974 yllında Aziz Üstel ve 1989 yllında Sinan Fişek tarafından yapılan çevirilerini karşılaştırmalı olarak inceleyerek, romanın biçemsel özelliklerinin çevirilere nasıl aktarıldığına ışık tutmayı amaçlamaktadır. İki çevirinin bu bakımından karşılaştırılması, yeniden çevirinin neden yapıldığına da açıklık getirebilir. Yeniden çevirinin nedenlerinden birinin, kaynak metnin biçemsel özelliklerinin erek metne daha etkili bir şekilde yansıtılmak istenmesi olabileceği görüşünden hareketle (Berman, 1990, s. 5; Deane-Cox, 2014, s. 104), bu çalışmada Lowry'nin romanının Türkçeye yeniden çevrilmesinin ardında biçemsel bir motivasyonun bulunup bulunmadığı gözlemlenecektir. Çalışmanın kalan kısmında, Lowry'nin romanında öne çıkan zihinsel biçemin çevirilerde incelenebilmesi için ilk olarak zihinsel biçem kavramı ele alınacak ve bu kavramı mercek altına alan bilişsel biçembilimin çeviribilim ile ilişkisi üzerinde durulacaktır. Çalışma yönteminin açıklanması ve çevirilerin incelenmesinin ardından, sonuç bölümünde yukarıda belirtilen soruların cevaplarına ışık tutulacaktır. 


\section{Zihinsel biçem ve çeviri ilişkisi}

\subsection{Zihinsel biçem nedir?}

Biçembilimin alt alanı olan bilişsel biçembilim, dil kullanımının zihinsel yapılardan nasıl etkilendiğini inceleyerek, yazın metinlerinin okunma ve yorumlanma şekillerine dair çalışmaların yürütülmesini sağlamaktadır (Stockwell, 2002, s. 15). Biçemin bilişsel biçembilim çerçevesinde incelenmesi için "dilbilimsel önceleme" ve "belirginlik" kavramları ön plana çlkmaktadır (van Peer, 1993, s. 48). Bu iki kavramın "psikolojik bir ilke" olarak düşünülmesi gerekir (van Peer, 1993, s. 48). Dilbilimsel önceleme ve belirginlik, anlatılarda yer alan herhangi bir dil ögesinin alışılmış ya da kurallarla düzenlenmiş olan halinden daha farklı bir şekilde kullanılarak ön plana çıarılması ile oluşturulur (van Peer, 1993, s. 48). Diğer bir değişle, yazın metinlerinde önceleme ve belirginlik, dilin beklenen kullanımlarından ve kurallı yapılarından sapma şeklinde orta çıkar.

Bilişsel biçembilim, yazın metinlerinde zihinsel biçemin nasıl oluşturulduğunu inceler. Zihinsel biçem, bilişsel özelliklere ışık tutan dil tercihleri olarak düşünülebilir. Zihinsel biçemin incelenmesini hedef alan çalışmalarda bir metnin yazarının, metindeki herhangi bir karakterin, ya da anlatıcının içinde bulunduğu psikolojik durumu ya da tecrübe ettiği bilişsel süreci değerlendirebilmek için dilbilimsel ipuçlarına başvurulmaktadır (Boase-Beier, 2014). Zihinsel biçem kurgusal anlatılarda psikolojik süreçlere ve yatkınlıklara ayna tutar; bir metnin okurda bıraktı̆̆ı etki ya da metnin bir karakteri, anlatıcısı ya da yazarı hakkında okur tarafından oluşturulan izlenim de zihinsel biçemin etkisi ile ortaya çlkmaktadır (Semino, 2007; Nuttall, 2018). Zihinsel biçem kavramı ilk olarak Fowler tarafından "zihnin belirgin ve bireye özgü olacak şekilde dil düzeyinde temsil edilmesi” şeklinde tanımlanmıştır (1977, s. 103). Zihinsel biçem "belirli bir bilişsel durumu yansıtan dil biçemi" olarak da tanımlanabilir (BoaseBeier, 2003, s. 257). Zihinsel biçemin en önemli özelliği okura "[metinde yaratılan] kurgusal dünyanın alışılmışın dışında algılandığını” gösterebilmesidir (Leech and Short, 1981, ss. 188-189).

Fowler’a göre, dil dünyayı algılama şeklimizi yansıtmakla kalmayıp, algı düzeyimizi de etkilemektedir (1996, s. 26). Dili kullanma ve algılama şekli, "meşrulaştırma" ve "normalleştirme" sayesinde dili kullanan kişiler tarafından "otomatikleştirilmiş" bir hale getirilmektedir (Fowler, 1996, s. 46). Bu nedenle, Bockting, zihinsel biçemi "bireyin kendisini ve [tüm] dünyayı algılayış şeklinin dilsel olarak ifade bulması" olarak tanımlamaktadır (1994, s. 171). Olağandışı bir şekilde çalışan bir zihnin yazın metninde kurgusal olarak temsil edilmesi bilişsel biçembilimin araştırma sahasına girmektedir. Yazın metinlerinde "bilişsel işleyişin olağandışı bir şekilde gerçekleşmesi gibi, standart bilişsel yapılardan uzak olan, bilişsel eksiklik ya da bilişsel bir aksaklık barındıran, ender görülen, sıradışı, ya da sapkın olan bilişsel yapı[ların]" da incelenmesi gerekmektedir çünkü yazın metinlerine yansıyan bu tür bilişsel durumlar okurların metne dair algı ve yorumlarını da etkilemektedir (Margolin, 2003, s. 287). Bu nedenle, Nuttall, zihinsel biçemi "okuma esnasında oluşturulan deneyimsel/yaşantısal bir etki" ve "okur ile biçem arasında yaşanan bir etkileşim” olarak tanımlamaktadır (2018, ss. 31-32). Nuttall, zihinsel biçemi okurun zihninde kurulan "kurgusal bir bilinç" olarak ifade etmekle birlikte, okur ve metin arasındaki etkileşimin zihinsel biçem kanalıyla oluşturulduğunu vurgulamaktadır (2018, s. 32). Bu da bilişsel biçembilimin okur-odaklı çalışmalarda da kullanılabileceğini göstermektedir.

Zihinsel biçemin yazın metinlerine yansıma şekli sözcükler, sözdizimi, geçişlilik, dışbağlamsal yapılar (deiksis), kavramsal metaforlar ve imgesel dil yoluyla gerçekleşmektedir (Fowler, 1977; Semino, 2002). Örneğin, yazın metinlerinde otistik olarak tanımlanan bireylerin zihinsel biçemlerinin incelenmesi kullandıkları dilin mercek altına alınması ile gerçekleştirilmektedir (Semino, 2007). Fowler tarafından 
da belirtildiği gibi, belirli bir bağlama uygun düşmeyen bir sözcüğün kullanılması ya da sözcüğün kullanımına uygun olmayan bir şekilde kullanılması zihinsel biliş düzeyinin yeterince gelişmemiş olduğuna işaret edebilir (1996, s. 216). Bir sözcüğün hiç gerekmediği halde yinelemeli bir şekilde kullanılması ya da aynı anlama gelen sözcüklerin aynı bağlamda ardı ardına kullanılması, sözcüğü kullanan kişinin (yazar, karakter ya da anlatıcı) takıntılı bir zihinsel yapıya sahip olduğunu gösterebilir (Fowler, 1996, s. 216).

Leech ve Short'un belirttiği gibi, sadece "olağan dışı dil kullanımlarından sapan” ya da "öncelenmiş" olan örneklerin biçembilimciler açısından önem teşkil ettiğini unutmamak gerekmektedir (1981, s. 24). Bu nedenle, alışılmışın dışında ve sapkın olarak kabul edilen dünya görüşüne sahip karakterlerin zihinsel biçemi de biçembilimcilerin sık başvurdukları örnekler arasında yer almaktadır (Semino \& Swindlehurst, 1996, s. 145; McIntyre, 2006, s. 144). Buna ek olarak, olağan dışı psikolojik ve zihinsel özelliklere (örneğin, şizofreni ve depresyon) sahip kişilerin zihinsel işleyişi yazın alanında başlica çalışma konuları arasında yer alabilir. Suç işlemeye yatkınlığı olan kişilerin dil kullanımlarının yazın metnine nasıl yansıtıldığı da zihinsel biçem araştırmaları açısından büyük bir önem taşımaktadır.

\section{2. Çeviride zihinsel biçem}

Yazın çevirisinin amacı kaynak metne yansıyan bilişsel durumun erek metin okuru tarafından da fark edilebilir olmasını sağlamak ise, kaynak metnin yazarının, metin içindeki bir karakterin ya da anlatıcının bilişsel durumuna ilişkin bağlamsal ipuçları veren biçemsel unsurların erek metinde yeniden oluşturulması gerekmektedir. Boase-Beier tarafından da belirtildiği gibi, zihinsel biçem kavramı çeviri kuramı çerçevesinde belirli bir "bilişsel duruma" ayna tutan bir dizi "sezdirimsel ipucu" şeklinde ele alınabilir (2014, s. 44). Okur, çevirmen tarafından oluşturulan ve metne ilişkin varsayımda bulunulmasını sağlayan bu ipuçlarının ışığında öne çıan zihinsel biçemin farkına vararak metni yorumlama sürecine girebilir.

Zihinsel biçemin en ilginç örneklerinden birisi James Joyce'un $A$ Portrait of the Artist as a Young Man (Sanatçının Bir Genç Adam Olarak Portresi) adlı eserinde ve Murat Belge tarafından yapılan Türkçe çevirisinde Stephen Dedalus'un çocukluktan ergenliğe doğru yol alışına ilişkin anlatıda geçen çocukluk bilincinin dile nasıl yansıtıldı̆̆ıdır:

\section{KM:}

Once upon a time and a very good time it was there was a moocow coming down along the road and this moocow that was coming down along the road met a nicens little boy named baby tuckoo. His father told him that story: his father looked at him through a glass: he had a hairy face. He was baby tuckoo. The moocow came down the road where Betty Byrne lived: she sold lemon platt. (Joyce, 2011, S. 1)

EM:

Evvel zaman içinde ve ne güzel evvel zamanlardı onlar bir küçük mööinek varmış yoldan aşağı inen ve yoldan aşağı inen bu küçük mööinek tuku bebek adında cici bir küçük çocuğa rastlamış... Bu masalı ona babası anlattıydı, babası ona bir camın arkasından bakardı: Kıllı bir yüzü vardı. Tuku bebek oydu: Mööinek Betty Byrne'ün yaşadığı yerdeki yoldan aşağı iniyordu: Betty Byrne limonlu pasta satardı (Joyce, 2016, s. 59).

Yukarıdaki paragrafta da görülebileceği gibi, çocuk zihninin işleyişine özgü biçem sözcük tercihleri ile metne yansitılmıştır. "Moocow" ve "tuckoo" gibi çocuklara özgü sözcüklerle birlikte, karakterin uydurmuş olduğu "nicens” sözcüğü kaynak metinde öncelenmiştir. Çevirmen Murat Belge de kaynak metne yansıyan bu bilişsel durumu "mööinek", "tuku" ve "cici" gibi sözcüklerle başarılı bir şekilde 
yeniden oluşturmuştur. Çevirmen tarafından yapılan bu tür sözcük tercihleri erek dil okurunun metni yorumlama sürecinde etkili olmaktadır.

Boase-Beier'e göre, okurun yorumlama sürecine girebilmesi için metni etkileyen zihinsel biçemin farkında olması gerekmektedir (2003). Diğer bir deyişle, zihinsel biçem, ancak okurun zihni ile metne yansıyan kurgusal zihin arasında bir etkileşimin ortaya çıkması durumunda okur üzerinde belirli bir etki bırakabilir. Bu nedenle, zihinsel biçeme okur-odaklı yaklaşlarak belirli bir dil kullanımının okurda nasıl bir izlenim yarattığının ve bu izlenimin nasıl farkına varıldığının araştırılması gerekir. Bu iki soru özellikle yazın metinleri çevirisinde kaynak dildeki zihinsel biçemin erek dilde yeniden oluşturulabilmesi için oldukça önemlidir.

Sözcük tercihine ek olarak, okurda bir izlenim yaratmak için kullanılan unsurların arasında sözdizimi başı çekmektedir (Fowler, 1977: 104). Joyce'un Ulysses eserinde Leopold Bloom karakterinin zihinsel biçemi kaynak metne ve Nezat Erkmen tarafından yapılan Türkçe çevirisine aşağıdaki şekilde yansitılmaktadır:

\section{KM:}

Gasworks. Whooping cough they say it cures. Good job Milly never got it. Poor children! Doubles them up black and blue with convulsions. Shame really. Got off lightly with illness compared. Only measles. Flaxseed tea. Scarlatina, influenza epidemics. Canvassing for death. Don't miss this chance. Dogs' home over there. Poor old Athos! Be good to Athos, Leopold, is my last wish. Thy will be done. We obey them in the grave. A dying scrawl. He took it to heart, pined away. Quiet brute. Old men's dogs usually are. (Joyce, 1992, s. 87)

EM:

Havagazı tesisleri. Boğmacaya iyi gelir derler. Şükür Milly hiç yakalanmadı. Zavallı yavrucuklar! Öksürükten katılır mosmor kesilirler. Reva mı yani? Hastalıktan yana nispeten ucuz atlattı sayılır; Sadece kızamık. Ketentohumu lapası. Kızıl, grip salgınları. Azrail kol geziyor. Bu firsatı kaçırma. Sokak köpekleri barınağı şurda. Zavallı yaşlı Athos! Athos'a iyi davran. Leopold, son dileğim budur. Hiç merak etme sen. Onlar ölene dek dinleriz. Ölüm döşeğinde kargacık burgacık yazısı. Dünyası zindan olmuş, gözünde fer kalmamıştı. Durgun bir hayvan. Yaşlı insanların köpekleri böyle oluyor ekseri (Joyce, 1996, s. 140).

Yukarıdaki paragrafta da görüldüğü gibi, kaynak metindeki karakterin anlatısında sözdizimi kurallarına uyulmaması, eksiltili cümlelerin sıklıkla kullanılması ve söz diziminin belirli bir fikrin geliştirilmesine katkıda bulunamaması gibi faktörler karakterin anlatısının bir mantık silsilesi içinde ilerlemediğini ve karakterin düşük bir entelektüel düzeye sahip olduğunu göstermektedir (Fowler, 1977, s. 104). Bu örnekte, sözdizimi, karakterin bilişsel durumuna ilişkin olarak okura ipucu vermektedir. Söz konusu paragrafın Türkçe çevirisine bakacak olursak, "whooping cough they say it cures" ("[b]oğmacaya iyi gelir derler") gibi cümlelerin Türkçe sözdizimi kurallarına uygun olarak çevrildiğini görmekteyiz. Bu durum, çeviri sürecine ya da çeviri sonrası sürece dâhil olan (çevirmen, editör ve/veya yayınevi sahibi gibi) aktörlerin çeviride dilin düzgün kullanılmasını istemiş olmasından ya da erek kültürde okuma sürecinin akıcı olmasına dair bir beklentinin oluşmasından kaynaklanmış olabilir.

Çeviride zihinsel biçeme ilişkin olarak göz önünde bulundurmamız gereken en önemli nokta, çevirmenlerin metinde "bilişsel bir durumu sergileyen iletişimsel ipuçları[ndan]" faydalanarak erek okurun metni anlamdırma ve yorumlama sürecine etki edebileceğidir (Boase-Beier, 2014, s. 109). Bilişsel biçembilim, bağlam kavramını bilişsel bir bütün olarak ele almaktadır; bu nedenle, bağlamın insanlar tarafından yorumlanmasına etki eden toplumsal ve kültürel unsurların da çevirmen tarafından göz önünde bulundurulması gerekir. Örneğin, Joyce'un $A$ Portrait of the Artist as a Young Man romanında çocuğun bilişsel durumunun bir yansıması olarak "ve" bağlacının çok sık kullanıldığını 
gözlemleyen bir çevirmenin erek dilde hangi bağlacın çocuklar tarafından sıklıkla kullanıldığını düşünerek erek metnin biçemini şekilledirmesi gerekebilir.

\section{Under the Volcano eserinin Türkçe çevirilerinde zihinsel biçem analizi}

\subsection{Yöntem}

Yazın alanında biçem çalışmaları genellikle konuşma ve diyaloglara odaklanmaktadır, ancak karakterin algı ve bilinç düzeyinin dışa vurumu olarak ortaya çıkan bazı anlatılarda da biçem çalışmaları yapılabilir (Rundquist, 2014). Bu bağlamda, serbest dolaylı anlatım, zihinsel biçem çalışması yapılabilecek verimli bir araştırma alanıdır (Rundquist, 2020). Serbest dolaylı anlatım, karaktere özgü bir bakış açısı ve karaktere özgü ifadelerin kullanımı sayesinde okurun karakterin iç dünyasına girmesini sağlayan bir teknik olarak kullanılmaktadır. Bu teknik karakterin iç dünyasını ve psikolojisini okura aktararak, okurun metne ilişkin birtakım varsayımlarda bulunmasını sağlar. Serbest dolaylı anlatım, karakterin öznelliğinin dışa vurumunu kolaylaştırır ve karakterin zihinsel faaliyetlerinin dil düzeyinde ifade bulmasını sağlayan "mimetik bir teknik" olarak kullanılır (Adamson, 1998, s. 662). Başka bir deyişle, serbest dolaylı anlatım diyaloglarla söze dökülmemiş olan zihinsel deneyimlerin dile aktarımı görevini yerine getirmektedir. Bu nedenle, Riquelme bu tekniği "zihnin taklidi” ya da zihnin dışa vurumu olarak tanımlar (1983, s. 198).

Modernist yazarlar, karakterlerinin bilinç akışını dil düzeyine yansıtmak ister (Chatman, 1978, s. 178). Eserlerinde "psikolojik gerçeklik" yaratmak isteyen Lowry gibi modernist yazarlar serbest dolayl anlatım tekniğinden yararlanmaktadır (Bradbury, 1973, s. 124). Lowry, romanındaki alkolik başkarakteri okur ile buluştururken diyaloglar kadar serbest dolaylı anlatım tekniğinden de yararlanmıştır (bkz. Rundquist, 2020). Dil yapılarının zihinsel süreçlerin bir yansıması olarak ortaya çıktığı düşüncesinden hareketle (Evans, 2012), zihinsel faaliyetlerin serbest dolaylı anlatıma nasıl yansıdığını incelemek için bilişsel biçembilime başvurabiliriz. Bilişsel dilbilimcilere göre, dilin (sözcük, sözdizimi ve sesdizimi gibi) her düzeyi temel bilişsel ilkeler aracıllğıyla açılanabilir çünkü dil bilişsel düzeyin ayrılmaz bir parçasını oluşturur (Nuttall, 2018, s. 33). Bilişsel dilbilime göre, biliş insanların "dünyayı bedensel olarak deneyimleme" şeklini etkilemektedir (Nuttall, 2018, s. 34). Bu nedenle, insan bedeni, gerçekliğin algılanma şeklini sınırlandırmakla kalmayıp, bu gerçekliğin dil yoluyla ifade edilme şekline de sinırlar koymaktadır (Nuttall, 2018, s. 34).

Bilişsel dilbilimin penceresinden baktı̆̆ımızda, belirli bir zihinsel biçemin oluşmasını sağlayan ve sistematik bir şekilde tekrarlanan dil kullanımları insanların bilişsel yeteneğinin, duyusal deneyiminin ve daha geniş bir bağlamda fiziksel ve toplumsal çevresinin bir sonucu olarak ortaya çıkabilir (Nuttall, 2018: 34). Okur, okuma sürecinde, "sezgileri" sayesinde alışlagelmiş kurallara uyan dil kullanımlarını göz önünde bulundurarak, "kemikleşmiş hale gelen bilişsel rutinlerden" sapan ve "yabancllaştırma" etkisi yaratan dil kullanımlarının farkına varabilir (Nutall, 2018, s. 34).

Bu çalışmada, Nutall'ın ifadesiyle (2018, s. 34), olağan hale gelen "bilişsel rutinlerden" sapan ve "yabancılaştırma" etkisi yaratma potansiyeline sahip olan biçemsel ipuçlarından seçilen ve metnin bütününde geçen dil kullanımlarını temsil eden örneklerin ışığında, Under the Volcano adlı roman ve romanın iki Türkçe çevirisinde Konsolos adlı başkarakterin zihinsel biçemi hem diyalogların hem de serbest dolaylı anlatımların betimsel olarak sözcük ve sözdizimi düzeyinde karşılaştırılması yoluyla incelenecektir. 


\subsection{Sözcük düzeyinde zihinsel biçemsel aktarımı}

\section{Örnek 1:}

ST:

Oh we alll WALK ze wibberlee wobberlee WALK

And we alll TALK ze wibberlee wobberlee TALK

And we alll WEAR wibberlee wobberlee TIES

And-look-at-all-ze-pretty-girls-withwibberlee-wobberlee eyes. Oh.

We alll SING ze wibberlee wobberlee SONG

Until ze day is dawn-ing,

And-we-all-have-zat-wibberlee-wobberleewobberlee-

wibberlee-wibberlee-wobberlee feeling

In ze morning (Lowry, 2012: 68)

TT1:

Yalpalaya yalpalaya yürürüz biz,

Kekeme kekeme konuşuruz biz

Alacalı bulacalıdır boyunbağımız.

Ah yalpalaya yalpalaya yürüyen şu kızlara

Kekeme kekeme konuşan şu kızlara

Alacalı bulacak giysili kızlara BAK! (Lowry, 1974: 27)

TT2:

"Dingala dingala yürürüz biz

Dingala dingala konuşuruz biz

Dingala dingala kravatlarımız

Dingala gözlü kızlara bakarız

Gün doğana kadar

Dingala dingala türkü yakar

Sabahları kafalar

Dingala dingala dingala dingala

kalkarız." (Lowry, 1989: 32)

Yukarıdaki örnekte Konsolos'un bilişsel durumunu sözcük düzeyinde temsil etmek için alkollü iken "wibberlee" ve "wobberlee" gibi anlamsız sözcüklerin kullanıldığını görmekteyiz. Birinci çeviride "yalpalaya yalpalaya yürü[mek]", "kekeme kekeme konuş[mak]" ve "alacalı bulacalı [giyinmek]" gibi ifadeler kullanılarak, alkolün Konsolos'un davranışları üzerindeki etkisi erek okura yansıtılmaya çalışılmıştır. İkinci çeviride ise, kaynak metinde olduğu gibi, birlikte kullanıldığında anlam ifade etmeyen sözcüklerin (örneğin, “dingala gözlü”) bir araya getirilmesi ile alkolün Konsolus’u bilişsel düzeyde nasll etkilediği gösterilmektedir. 


\section{Örnek 2:}

KM:

"This-" she glanced contemptuously round the dark little bar, "was never in my mind. Life changes, you know, you can never drink of it."

“Not 'drink of it,' Señora Gregorio, you mean 'think of it.” (Lowry, 2012: 409)

EM1:

—«Burası pislik oldu. Yaşantı değişiyor gün be gün. İçemiyor insan.»

—«Düşünemiyor, Bayan Gregorio içemiyor değil.»

— «̇́çemiyor ya...» (Lowry, 1974, s. 233).

EM2:

"Bunu,” -karanlık küçük bara küçümseyerek göz gezdirdi- “aklımdan bile geçirmemiştim. Hayat değişiyor, hiç düişülmüyor bile.”

“Düşülmüyor' değil, Senora Gregorio, 'düşüinülmüyor' demek istiyorsunuz.”

“Düşülmüyor bile. Her neyse,” dedi [...] (Lowry, 1989, s. 258).

Kaynak metinde yapılan kelime oyunu sayesinde ("think of it" yerine "drink of it" kullanılması), Konsolos'un alkolün etkisi ile sözcükleri bağlama uygun olarak kullanamadığı gösterilmektedir. Bu etki her iki çevirmen tarafından da erek metin okuru için yeniden oluşturulmuştur. Birinci çeviride aynı kelime oyunu (hayatı içmek ve hayatı düşünmek) kullanılmıştır; ikinci çeviride ise benzer seslere sahip kelimelerin (düşülmek ve düşünülmek) kullanımı tercih edilerek, Konsolos'un zihinsel düzeyde yaşadığı karmaşa ön plana çıkartılmaya çalışılmıştır. Kaynak metinde zaten var olan bir anlaşmazlığın okura yansıtılması söz konusu olduğundan, her iki çevirmenin de bu anlaşmazlığı benzer kelime oyunları ile yeniden oluşturmaktan başka bir seçenek kullanmadığı görülmektedir.

\section{Örnek 3:}

KM:

as he turned by accident, into a strangely subaqueous view of the plains and the volcanoes with a huge indigo sun multitudinously blazing south southeast. Or was it north northwest? He noted it all without sorrow, even with a certain ecstasy, lighting a cigarette, an Alas (though he repeated the word "Alas" aloud mechanically) then, the alcohol sweat pouring off his brows like water, he began to walk down the path toward the fence separating his garden from the little new public one beyond that truncated his property. (Lowry, 2012, ss. 244-245)

\section{EM1:}

Başını çevirip yanardağlara baktı. Çivit rengi güneş Güney-Güney-Doğu'da pırıl pırıldı. Yoksa Kuzey-Kuzey-Batı'mıydı? Üzüntüyle doğayı selamladı. Cigarasını yaktı. Alkol, tere dönüşmüş şıpır şıpır damlamaya başlamıştı alnından. Yavaş yavaş yürüdü. Bahçesiyle bitişiğindeki parkı ayıran parmaklığa doğru gitti (Lowry, 1974, s. 134)

\section{EM2:}

[...] ama bu düzen ister istemez acayip bir biçimde suyun altından görülüyormuş gibi duran ovaların yanardağların ve güney-güneydoğu yönünde mavi mavi parlayan kalabalık bir güneşin düzenine karışıyordu. Yoksa kuzey-kuzeybatı mıydı? Bütün bunları üzüntüsüz hatta, belli bir keyifle gözlüyordu; bir sigara, bir Alas yakti, (yazık demekti bu - yazık sözcügünü yüksek sesle yineledi) sonra, alnıdan alkol terleri su gibi akarak patikadan aşağı, bahçesini bölen yeni açılmış küçük halka açık parkla bahçeyi birbirinden ayıran tel parmaklığa yürüdü (Fişek, 1989, s. 149)

Konsolos'un serbest dolaylı anlatımından oluşan üçüncü örnekte, Shakespeare'e yapılan iki farklı anıştırma ile kahramanın zihinsel durumunun normal olmayışının okura yansitılması amaçlanmaktadır. Anıştırmalardan ilki, Macbeth’in “[h]e says, 'Will all great Neptune's ocean wash this 
blood clean from my hand? No, this my hand will rather the multitudinous seas incarnadine, making the green one red" ifadesinde geçen ünlü "multitudinous seas" (çok sayıda dalga) sözünü akıllara getirmektedir (Shakespeare, 2015, s. 44). Macbeth'in ellerindeki kanın denizdeki su ile temizlenemeyeceğini anlatabilmek için söylediği bu sözler, oyunun çevirisini yapan Eyüboğlu tarafından Türkçeye "[e]lime bulaşan kanı Neptün'ün tüm okyanusları temizleyebilir mi? Hayır, tersine, yeşil denizin sayısız dalgalarını kızıl bir okyanusa dönüştüren, bu el olacak” şeklinde aktarılmıştır (Shakespeare, 1981, s. 57).

İncelediğimiz örnekteki ikinci anıştırma ise Hamlet’in hafızalara kazınan "I am but mad north-northwest: when the wind is southerly I know a hawk from a handsaw" ifadesini akıllara getirmektedir (Shakespeare, 1994, s. 80). Bu ifade Hamlet çevirisini yapan Bozkurt tarafından Türkçeye "[b]en yalnızca kuzey-kuzeybatıda kaçı̆̆ım. Rüzgâr güneyden estiğinde atmacayı balıkçıldan iyi ayırırım" şeklinde aktarılmıştır (Shakespeare, 1999, s. 101). İncelediğimiz kaynak metinde Macbeth ve Hamlet adlı oyunlara yapılan anıştırmaların amacı yaşadığı trajedi ile sarsılan Machbet'in ve intikam hırsı ile deliye dönen Hamlet’in durumu ile, alkolizm nedeniyle ruhsal ve zihinsel bir çöküş yaşayan Konsolos'un durumu arasında bir bağlantı kurmaktır.

Kaynak metinde güneşi niteleyen "multitudinous" (çok sayıda, kalabalık) anıştırmasına 1974 yllı çevirisinde yer verilmezken, anıştırma yeniden çeviride "kalabalık güneş" olarak çevrilmiştir. Bu şekilde, yeniden çeviride Konsolos'un yaşadığı zihinsel karışıklık nedeniyle sözcükleri bağlama uygun olarak kullanamaması ("kalabalık güneş" ile) erek metne yansıtılmıştır. Burada dikkat edilmesi gereken nokta, çevirmenin "kalabalık güneş" yerine "sayısız güneş ışını" gibi bir ifade kullanmamasının altında yatan nedeninin sözcük düzeyinde kaynak metne yansıyan zihinsel biçemin erek metinde yeniden oluşturulmaya çalışılmasından kaynaklanmış olabileceğidir.

1974 ve 1989 çevirilerinde ikinci anıştırmaya nasıl yer verildiğine bakacak olursak, birinci çevirideki “Güney-Güney-Doğu'da [...]. Yoksa Kuzey-Kuzey-Batı'mıydı?” ve ikinci çevirideki "güney-güneydoğu yönünde [...]. Yoksa kuzey-kuzeybatı mıydı?” ifadeleri ile Konsolos'un hezeyanının Hamlet’in yaşadığı hezeyana yapılan gönderme üzerinden erek metne yansıtıldığını görebiliriz.

\section{Örnek 4:}

KM:

Mr Quincey's words knocked on his consciousness - or someone actually was knocking on a door - fell away, then knocked again, louder. Old De Quincey; the knocking on the gate in Macbeth. Knock, knock, knock: who's there? Cat. Cat who? Catastrophe. Catastrophe who? Catastrophysicist. What, is it you, my little popocat? Just wait an eternity till Jacques and I have finished murdering sleep? Katabasis to cat abysses. Cat hartes atratus. (Lowry, 2012, s. 140)

EM1:

Quincy'nin sözleri bilincini tıklattı. Yoksa biri kapıyı mı vuruyordu? Ses kesildi. Yeniden başladı. Bu kez daha yükssek. Yaşlı De Quincy; Macbeth’in içindeki kapıya vuruluyor. Tık, tık, tık: kim var orada? Fel? Ne Fel'i? Felâket. Hangi Felâket? Felâket Habercisi. Aaa, sen misin popokedi? Miyavlama, duydum ve de geliyorum. Bekle, bekle. Sonsuzluğa değin bekle. Bu arada Jack'la ben uykuyu öldürüverelim. Yürek denen varlığın uykuya yatmadan önceki son tık tıklarıydı bunlar tabiî! (Lowry, 1974, ss. 141-142)

\section{EM2:}

Quincey'nin sözleri bilincine vuruyor -ya da birisi gerçekten bir kapıya vuruyordu-, geri duruyor, sonra gene, daha sertçe vuruyordu. Aslan De Quincey; Macbeth'de kapıya vuruluyor: tık, tık, 
tık: Kim o? Kedi. Hangi kedi? Fe- lakedi. Ne felaketi? Evrenin felaketi. Ne o sen misin, küçük Popokedim? Bir sonsuzluk boyu bekleyebilir misin, Jacques'la ben uykuyu katledene kadar? Kedibasis'ten kedi abisine. Kedihartes atratus (Lowry, 1989, s. 158).

Başkarakterin serbest dolaylı anlatımından oluşan bu örnek anıştırmalarla doludur. Bilişsel durumu alkolün etkisiyle karmakarışık bir hale gelen Konsolos, bir yandan önceden okuduğu ve ancak entelektüel düzeyi yüksek olan kişilerin bilebileceği yazın metinlerine, mitolojik hikayelere ve önemli olaylara gönderme yaparken, diğer yandan bu tür olayları basit ve sıradan olaylarla karıştırmakta ve hepsini aynı bağlamda kullanmaya çalışmaktadır. Kaynak metindeki anıştırmalardan biri "murdering sleep" ifadesi ile oluşturulmuştur. Shakespeare'in Macbeth oyununda geçen "[s]leep no more! Macbeth does murder sleep" (2015, s. 57) ifadesi, düşmanlarını uykuda öldüren Macbeth’in artık uyuyamayacağını çünkü sadece masum insanların huzurlu uyuyabileceğini anlatmaktadır.

Diğer bir anıştırma ise Thomas de Quincey'in 1823 yılında yazdığı "On the Knocking on the Gate in Macbeth" ("Macbeth’te Kapının Vuruluşu Üzerine”) adlı yazı ile ilgilidir. Söz konusu yazıda, kapının vuruluşunun Macbeth’i uykusundan uyandıramasa da vicdanının uyandırılmasına yardımcı olduğundan bahsedilmektedir (de Quincey, 1993, s. 7). Konsolos'un dünyanın insani ve şeytani boyutlarının farkına vardığını anlatan yukarıdaki örnekte, "knock" kelimesinin sistematik olarak tekrar edilmesi kahramanın adı geçen yazıya gönderme yaptığının vurgulanması açısından önem taşımaktadır. Diğer yandan, "[k]nock, knock, knock: who's there" ifadesinde ise bir çocuk oyununa gönderme yapılmaktadır. "Knock" sözcügünün geçtiği önemli bir yazın metnine ve sıradan bir çocuk oyununa yapılan anıştırmaların aynı bağlamda kullanılması bir tezat oluşturmaktadır. Bu tür tezatlar, Konsolos'un bilişsel düzeyde yaşadığı karmaşayı biçemsel düzeyde ortaya çıkarmaktadır.

Metinde benzer bir etki "cat” sözcüğü ile aynı heceye sahip olan kelimelerle yaratılmaya çalışılmıştır: "cat” (kedi), "catastroph" (afet), "catastrophysicist” (afetlerle ilgilenen astrofizik bilimi ile uğraşan kişi) sözcükleri ile birlikte kullanılan "popocat”, Meksika'da patlamaya hazır bir yanardağ olan Popocatépetl'a gönderme yapmaktadır. Ayrıca, Aristoteles'in Poetika eserinde geçen ve bir olay örgüsünde gerilimin düştügünü gösteren bir terim olan "katabasis" sözcüğü de kullanılmıştır (Dobrov, 2001, s. 206). Bu terim, aynı zamanda, bazı kahramanların gelecekten haber getirmek veya bir engeli aşmak için girdikleri bir maceraya işaret etmektedir (Dobrov, 2001, s. 206). "Katabasis", Yunan mitolojisinde (örneğin, Orpheus'un yeraltına yolculuğu) çok sık kullanılmış olup, bir zorluğu atlatmak için yeraltı dünyasına giriş yapma anlamını da taşımaktadır (Dobrov, 2001, s. 206).

İngilizce okunuşunun yaptığı çağrışımdan dolayı kaynak metinde "katabasis" terimini "cat abysses" ve "cat hartes atratus" sözcükleri takip etmiştir. "Cat hartes atratus", yenidünya akbabasıgiller familyasından olan bir kuş türüdür. Tüm bu sözcüklerin bir yazın metninde birarada kullanılması okura saçma gelebilir, ancak biçemsel düzeyde sözcüklerle oluşturulan bu etki Konsolos'un zihinsel yapısının ne kadar karmaşık olduğunu gözler önüne sermektedir.

Romanın iki çevirisinde de Macbeth bağlamında "tıklatmak", "tık tık" ve "kapı[ya] "vur[mak]" gibi sözcükler bir arada kullanıldığından kaynak metindeki anıştırmanın erek okur için oluşturulduğunu söyleyebiliriz. 1974 çevirisinde "cat" hecesi kullanılarak yapılan kelime oyunları ve anıştırmalar, "felaket”, "felaket habercisi” ve "popocat" sözcüklerindeki seslerle sınırlı kalmış; "katabasis" ve "cat hartes atratus" gibi sözcükler çeviriden çıkarılmıştır. Bu durumun nedeni, çevirideki ifadelerin gitgide daha saçma bir hale gelmesini önlemek olabilir. 
1989 yll çevirisinde ise "kedi”, "fe-lakedi”, "ne felaketi”, "evrenin felaketi” ve "popokedi” sözcükleri ile kaynak metindeki etkiye benzer bir etki sağlanmıştır. Bu çeviride, ayrıca, "katabasis" ve "cat abyss" arasındaki ses ilişkisi "kedibasis" ve "kedi abisi" ile oluşturulmaya çalışılmış ve "kedihartes atratus" sözcüğü de çeviride yer bulmuştur. Erek metin okuru bu sözcüğü bilmiyor olsa bile, kaynak metinde Konsolos'un kullandığı sözcükler arasında önemli bir anlam ilişkisi bulunmadığından, sözcüğün çeviride yer alması, Konsolos'un zihninin ne kadar bulanık olduğunun erek okura gösterilmesi açısından önem taşımaktadır.

Konsolos'un zihin karmaşası, özellikle de “murdering sleep” anıştırmasında görüldüğü gibi, kullandığı yazınsal ifadeler ve önemli eserlere yaptığı göndermeler sayesinde dile getirdiği ve metnin bağlamında herhangi bir anlam ifade etmeyen sözcüklerle daha açık bir şekilde gözler önüne serilmektedir. Macbeth oyununun Sabahattin Eyüboğlu tarafindan yapılan çevirisinde "[s]leep no more! Macbeth does murder sleep” ifadesi Türkçe'ye “[k]imseler uyumasın artık! Macbeth uykuyu öldürdü” olarak aktarılmıştır (Shakespeare, 1981, S. 41). Bu oyuna yapılan anıştırmanın, romanın 1974 ve 1989 çevirilerinde korunarak, sırasıyla “uykuyu öldür[mek] ve "uyukuyu katle[tmek]" şeklinde aktarılması, Konsolos'un çok ünlü bir oyuna gönderme yapabilecek kadar entelektüel olduğunu, ancak yazın metinlerinin ve mitolojik hikayelerin konularını barda yaşadığı sıradan olaylarla karıştıracak kadar da bulanık bir zihinsel yapıya sahip bulunduğunu göstermektedir.

\subsection{Sözdizimi düzeyinde zihinsel biçem aktarımı}

\section{Örnek 1:}

KM:

Soon, preposterous things were being said between them again without adequate reason: answers, it seemed to him, given by him to questions that while they had perhaps not been asked, nevertheless hung in the air. And as for some answers others gave, when he turned round, no one was there.

Lingeringly, the bar was emptying for la comida. (Lowry, 2012, s. 641)

\section{EM1:}

Saçma sapan şeyler söylemeğe başladılar. Konsolos dinlemiyordu bile. Yavaş yavaş meyhanenin içi boşalıyordu. (Lowry, 1974, s. 347)

\section{EM2:}

Bir süre sonra nedensiz yere gene saçma sapan şeyler söylemeye başladılar aralarında: Sorulmadıkları halde havada asılı duran sorulara yanıtlar vermekteydi sanki Konsolos. Bazı yanıtlar da başkalarından geliyordu ama dönüp baktığında kimse yoktu. Bar yavaş yavaş boşalıyordu la comida için. (Lowry, 1989, s. 410)

Bilişsel dilbilim, insanların düşüncelerini düzenleme biçimlerini, gerçekliği nasıl algıladıklarının dışa vurumu olarak görmektedir (Langacker, 1987, s. 105). Stockwell, sözdizimi düzeyindeki dilbilimsel ipuçlarını "okurun dikkatini çekmeyi amaçlayan metinsel unsurlar" olarak adlandırmaktadır (2002, s. 25). Kaynak metinde sürekli edilgen yapıların kullanılması ve fiilin bildirdiği işi yapan kişinin belirtilmemesi, Konsolos'un etrafında olan olayların farkında olamayacak kadar bilinçsiz bir durumda olduğunu göstermektedir (Rundquist, 2020: 12).

Roman boyunca, Konsolos'un serbest dolaylı anlatımında eksiltili cümleler kullanılması, cümlelerin başlangıç ve sonuç bölümünün farklı cümlelerle birbirinden ayrılması (örneğin, "answers, it seemed to him, given by him”) yine aynı zihinsel biçeme işaret etmektedir (Rundquist, 2020, s. 12). 1974 çevirisine 
baktığımızda, kaynak metin yapısındaki bu tür yapısal özelliklerin değiştirildiğini görebiliriz. Çeviride edilgen yapılar etken yapılara dönüştürülmüş (örneğin, "[s]açma sapan şeyler söylemeye başladılar”) ve sözdizimi nedeniyle meydana gelen anlam karmaşaları çeviriden çıkartılmıştır. 1989 çevirisine baktığımızda ise, edilgen yapıdaki cümlelerin bazılarının çeviride korunduğunu ("sorulmadıkları halde havada asılı duran sorular”), bazılarının ise etken yapıya dönüştürülerek edilgen yapılı cümlelerle arasında nicel açıdan bir denge sağlanmaya çalışıldığını görebiliriz. Bu türden bir dengenin sağlanmaya çalışılmasındaki amaç, çevirinin akıcılığını bozmamak ve okuru okuma sürecinde rahatsız etmemek olabilir. Ancak, 1989 çevirisinde akıcılığı korumak için yapılan bu tür biçemsel müdahaleleri telafi edebilmek için çevirinin akışını bozmayan devrik cümleler kullanılmıştır (örneğin, "[b]ar yavaş yavaş boşalıyordu la comida için”).

\section{Örnek 2:}

\section{KM:}

First the distant wail, then, the frightful spouting and spindling of black smoke, a sourceless towering pillar, motionless, then a round hull, as if not on the lines, as if going the other way, or as if stopping, as if not stopping, or as if slipping away over the fields, as if stopping; oh God, not stopping; downhill: clipperty-one clipperty-one: clipperty-two clipperty-two: clipperty-three clipperty-three: clipperty-four clippperty-four four: alas, thank God, not stopping, and the lines shaking, the station flying, the coal dust, black bituminous: Hckety-cut lickety-cut Hckety cut (Lowry, 2012, s. 282).

\section{EM1:}

Birbiri ardına trenler göründü. Titriyorlar: bir, iki, üç seraplar. Uzaktan bir çı̆̆lık; ürkütücü simsiyah duman, temeli belirsiz kapkarı yapı, boynuzlarını indirmiş, geceyarısı rengi bir boğa, raylardan çıkmış da ardına dönüp gidiyor; durdu duracak... durmadı durmayacak, tarlaların üstünden kayyor, durdu duracak; oooh Tanrım, durmuyor, yokuşaşağı: çuh-çuh bir çuhçuh bir: çuh çuh iki çuh-çuh iki: Çuh-çuh üç çuh-çuh üç: çuhçuh dört çuh çuh dört: sonunda, Tanrı'ya şükürler olsun, durmuyor, raylar titriyor, istasyon uçuyor, kömür tozu, yapışkan simsiyah: düüüüüt düüüt çuh-çuh-çuh-çuh-çuh-çuh-çuh pışşşşşş (Lowry, 1974, s. 286)

\section{EM2:}

Önce uzaktan gelen ulumaları, sonra fışkıran, dönen, korkunç kara duman, hareketsiz, temelsiz bir kule gibi yükselen bir yığın; sonra yuvarlak bir tekne, rayların üstünde değilmiş gibi ya da öbür yana gidiyormuş gibi, ya da duruyormuş gibi ya da durmuyormuş gibi ya da tarlaların üzerinden akıp gidiyormuş gibi, ya da duruyormuş gibi; Tanrım, duruyor olmasın; yokuş aşağı: dıgıdık-bir dıgıdık-bir: dıgıdık-iki dıgıdık-iki: dikıdik-üç dıgıdık-üç: dıgıdıkdört dıgıdık-dört: Heyhat, Tanrı'ya şükür, durmuyor ve raylar sarsılıyor, istasyon uçuyor, kömür tozu kara, ziftli: şıkıtı-tık şıkıtı-tık şıkıtı- tık (Lowry, 1989, s. 316).

Kaynak metinde "[f]irst the distant wail, then, the frightful spouting and spindling of black smoke, a sourceless towering pillar, motionless, then a round hull” ifadesinden sonra bir yüklemin gelmesi beklenmektedir. Ancak, Konsolos'un cümlesini böldüğü ve araya ardı ardına birbiriyle çelişen ifadeleri (örneğin, "as if not on the lines, as if going the other way, or as if stopping, as if not stopping, or as if slipping away over the fields, as if stopping; oh God, not stopping”) eklediği görülmektedir. Cümlenin öznesinden sonra gelmesi beklenen yüklemin Konsolos tarafından hiç kullanılmaması cümlede anlam kargaşası yaratmıştır. Christine Vandamme, bu durumu "anlatısal ve sözdizimsel derayman" olarak adlandırmaktadır (2016, s. 47). Başka bir değişle, anlamlı bir bütünden oluşan bir cümle bölünerek, araya anlatı ve sözdizimi bakımından cümlenin akışını bozan sözcüklerin eklenmesi (örneğin, clippertyone clipperty-one: clipperty-two clipperty-two: [...]) bir trenin raydan çlkmasına benzetilmektedir.

Kaynak metinde kullanılan “clipperty” sözcüğü ‘makasla kesmek' anlamına gelen 'clip' ve 'kırpma makası' anlamına gelen 'clipper' sözcüklerini çağrıştıran uydurma bir sözcüktür. Vandamme, Konsolos 
tarafından uydurulan bu sözcüğün, cümlenin mantıksal ve zamansal akışını bozduğunu ve cümlede "suni bir sözdizimi” yarattığını belirtmiştir (2016, s. 48). Cümledeki sözcük sıralamasında zaman ve mantık akışının bozulması, Konsolos'un zaman ve olaylar arasında sağlıklı bir bağlantı kuramadığını göstermektedir (Vandamme, 2016, s. 49).

Söz konusu paragrafın çevirilerine baktığımızda, 1974 çevirisinde cümlede geçen öznelerin birer yüklemle tamamlandığını ve anlam kargaşasının ortadan kaldııldığını görmekteyiz: "[b]irbiri ardına trenler göründü. Titriyorlar: bir, iki, üç seraplar. Uzaktan bir çı̆̆lı; ürkütücü simsiyah duman, temeli belirsiz kapkarı yapı, boynuzlarını indirmiş, geceyarısı rengi bir boğa, raylardan çıkmış da ardına dönüp gidiyor". Bu nedenle, "durdu duracak... durmadı durmayacak, tarlaların üstünden kayıyor, durdu duracak; oooh Tanrım [...]” ifadesi, cümlenin anlamında herhangi bir eksikliğe neden olmamıştır.

1989 çevirisinde ise özne konumunda olan "[ö]nce uzaktan gelen ulumaları, sonra fişkıran, dönen, korkunç kara duman, hareketsiz, temelsiz bir kule gibi yükselen bir yığın; sonra yuvarlak bir tekne" ifadesinden sonra bir yüklemin gelmemesi ve cümlenin "rayların üstünde değilmiş gibi ya da öbür yana gidiyormuş gibi, ya da duruyormuş gibi ya da durmuyormuş gibi ya da tarlaların üzerinden akıp gidiyormuş gibi, ya da duruyormuş gibi” ifadesi ile kesintiye uğratılması, kaynak metindeki sözdizimsel biçemin erek metinde de oluşturulabilmesini sağlamıştır. Ancak şunu da belirtmek gerekir ki, yeniden çeviride kesintiye uğrayan cümlelerin sayısı belirli ölçüde sınırlandırılmıştır. Çevirmen, kaynak metindeki ortaçları (the lines shaking, the station flying) kullanmak yerine, "[...] durmuyor ve raylar sarsilıyor, istasyon uçuyor" ifadelerinde olduğu gibi, özneleri yüklemlerle tamamlayarak cümlede akıcılığı sağlamaya çalışmıştır. Bu durumun nedeni, akıcılığı bozan bazı ifadelerin kullanımının çevirmen tarafından telafi edilmek istenmesi olabilir.

\section{Örnek 3:}

KM:

Nevertheless, the Consul thought, it was not merely that he shouldn't have, not merely that, no, it was more as if he had lost or missed something, or rather, not precisely lost, not necessarily missed.-It was as if, more, he were waiting for something, and then again, not waiting (Lowry, 2012, s. 295).

\section{EM1:}

Gene de diye düşündü Konsolos, birşey unuttum, ya da birşeyimi yitirdim, belki de birini bekliyorum. Gene de pek unuttum, gerçekten yitirdim sayılmaz. Gene de birini beklemiyorum (Lowry, 1974, s. 285).

\section{EM2:}

Gene de, diye düşündü Konsolos, yapmaması gerektiği için değildi, yalnız ondan değil, hayır, daha çok bir şeyi yitirmiş ya da kaçırmış gibiydi, daha doğrusu yitirmiş değil de, tam kaçırmış da değil. - Sanki daha çok bir şeyi bekliyormuş, ama gene de beklemiyormuş gibiydi (Lowry, 1989, s. 315).

Kaynak metinde Konsolos'un serbest dolaylı anlatımından oluşan cümlenin birçok defa kesintiye uğramasını, Konsolos'un cümleye devam edebilmek için bir türlü uygun sözcük bulamamasına bağlayabiliriz (Vandamme, 2016, s. 47). Örneğin, Konsolos "it was not merely that he shouldn't have" ifadesinde akışı tamamlamak için cümleye bir yüklem ekleyememiştir ve cümleyi "not merely that, no" ifadesi ile devam ettirmeye çalışmıştır. Başka bir değişle, Konsolos "shouldn't have" yapısına uygun bir sözdizimi sağlayamadığı için, cümleye "it was as if” yapısı ile devam etmek zorunda kalmıştır. 
Erek metinlere bakacak olursak, 1974 çevirisinin, yarıda kesilen kaynak metin cümlesini tamamladığını ve anlatım bozukluğunu giderdiğini görebiliriz. Dikkat çeken başka bir nokta ise 1974 çevirisinde Konsolos'a ait olan ve üçüncü tekil şahısa dayanan serbest dolaylı anlatımın birinci tekil şahısa dayalı doğrudan anlatıma dönüştürülmesidir. Kaynak metinde biçemsel ipuçlarını çok dikkatli takip eden bir okur tarafından serbest dolaylı anlatımın Konsolos'a ait olduğu sonucuna varılabilir. Ancak, biçemsel ipuçları dikkatli bir şekilde takip edilmezse, anlatının Konsolos'a mı yoksa başka bir karaktere mi ait olduğuna dair net bir sonuç elde edilemeyebilir. Bu noktadan hareketle, 1974 çevirisinde okurun işini kolaylaştırmak için, anlatının Konsolos'a ait olduğunun açık bir şekilde vurgulanmak istenmiş olabileceği sonucuna varabiliriz.

1989 çevirisi ise eksik cümlenin tamamlanması bakımından 1974 çevrisi ile aynı yolu izleyerek, "he shouldn't have, not merely that, no" ifadesindeki eksik yüklemi "yapmaması gerektiği için değildi, yalnız ondan değil, hayır," şeklinde tamamlamış ve oluşabilecek bir anlam kargaşasının önüne geçmeye çalışmıştır. Ancak, paragrafın kalan kısmına baktığımızda, 1989 çevirisinin sözdizimi düzeyinde kaynak metinde oluşturulan etkiyi oluşturmaya çalıştı̆̆ını görebiliriz.

\section{Sonuç}

Malcolm Lowry'nin modernist bir roman özelliklerini taşıan Under the Volcano adlı eserinin 1974 ve 1989 yıllarında yapılan Türkçe çevirilerini betimsel olarak inceleyen bu çalışma, romanda alkolizm sorunu nedeniyle bilinç karmaşası yaşayan ve çoğu zaman çevresinde olan bitenin farkında olmayan başkaraktere özgü zihinsel biçemin çevirilerde nasıl oluşturulduğunu gözlemlemeyi amaçlamıştır. Bilişsel biçembilim çalışmalarından hareketle, çalışmada, okurun metne dair birtakım varsayım ve çıkarımlara ulaşabilmesi için sözcük ve sözdiziminin, Boase-Beier’in ifadesiyle, nasıl bir "sezdirimsel ipucu" görevi üstlendiği gözlemlenmiştir (2014, s. 44).

Çevirilere sözcük düzeyinde bakıldığında, çoğu sözcüğü bağlama uygun olarak kullanamayan başkarakter Konsolos'un yaşadığı zihinsel bulanıklığın, romanın 1974 yılı çevirisinde cümlenin akışını ve anlamını tamamen bozmadığı durumlarda erek metne yansıtıldığı gözlemlenmiştir. Kaynak metinde yazınsal ifadelere ve önemli eserlere yapılan anıştırmaların, metnin bağlamında herhangi bir anlam ifade etmeyen sıradan ifadelerle bir arada kullanılması, Konsolos'un yaşadığı zihinsel karmaşayı önceleme amacını taşımaktadır. 1974 çevirisi Konsolos'un hezeyanını yansıtan ve önemli oyunlara, bazı mitolojik hikâyelere ve tarihsel olaylara yapılan pek çok anıştırmaya erek metinde yer vermiştir. Ancak, metnin bağlamında çok büyük tezatlara neden olan ve okurun okuma sürecini yarıda kesebilecek anlaşmazlıklar doğuran anıştırma ve ifadelerin çeviriden çıkartıldığı görülmüş̧ür. Diğer yandan, kaynak metinde biçemsel olarak öncelenen anıştırma ve ifadeler, büyük bir değişikliğe uğramadan 1989 çevirisine aktarılmıştır.

Kaynak metne sözdizimi düzeyinde bakıldığında, Konsolos'un serbest dolaylı anlatımlarında eksiltili cümleler kullandığı, bir cümleyi yarıda keserek başka bir cümleye başladığı ve bir cümlenin başlangıcı ve sonu arasına birbiri ile çelişen yeni cümleler eklediği görülmektedir. Romanın 1974 yılı çevirisinde, dil kullanımlarından sapma olarak görülen her türlü biçemsel unsur düzeltilerek, Türkçenin sözdizimi ve anlatım kuralları ile uyumlu hale getirildiği gözlemlenmiştir. 1989 yılı çevirisinde ise, kaynak metindeki sözdizimsel biçemin yer yer yeniden oluşturulduğu, bazı durumlarda ise erek okura akıcı bir okuma süreci sağlamak için anlatım bozukluklarının düzeltilerek, kaynak metnin biçeminden feragat edildiği ve anlam bütünlüğüne öncelik verildiği görülmüştür. Bu noktadan hareketle, 1989 yllı çevirisi tarafından, kaynak metnin sözdizimsel biçeminin korunması ile erek metnin okunabilirlik düzeyinin 
korunması arasında bir denge sağlanmaya çalışıldığını söyleyebiliriz. 1989 yllı çevirisinde gözlemlenen başka bir biçemsel özellik ise, kaynak metnin sözdizimsel biçemine akıcıllk adına müdahale edildiği, Türkçenin sözdizimine uygun hale getirildiği ve anlatım bozuklukluklarının giderildiği durumlarda - bir telafi stratejisi olarak- devrik cümlelerin kullanılmış olmasıdır. Devrik cümleler her ne kadar anlatım bozukluğuna yol açmıyor olsa da, erek metinde sadece Konsolos'a özgü bir dil kullanımının oluşturulması açısından önem kazanmıştır.

Bu bilgilerin ışığında, 1974 yılında yapılan çeviride, modernist bir roman olan Under the Volcano'ya damga vuran zihinsel biçemi oluşturan özelliklerin okuma sürecini yavaşlattığı ve anlam karmaşasına sebep olduğu durumlarda erek metinden çkartılmasının nedenini, 1980'li yıllardan önce modernist romanın biçemsel özelliklerinin Türk yazın dizgesinde her yönüyle ortaya çıkmamış olmasına ve Türk okurunun çevirinin yapıldı̆̆ı dönemde modernist romanın tüm özelliklerine aşina olmamasına bağlayabiliriz. 1989 çevirisinin incelenmesi sonucunda, yeniden çevirinin yapılmasının ardındaki temel motivasyonun romanın biçemsel özelliklerinin erek metne daha etkin bir şekilde yansıtılmak istenmesi olabileceği sonucuna varabiliriz. Ancak, bu çeviride de erek dil yapılarını tamamen bozan ve tümüyle anlam karmaşasına neden olan sözdizimi düzeyindeki bazı biçemsel özelliklerden feragat edildiği görülmüştür ve bu durum çeviride okunabilirlik düzeyinin belirli bir ölçüde korunmaya çalışılmasına bağlanmıştır.

Lowry'nin romanı ve Türkçe çevirileri bağlamında yapılan bu gözlemler çeviribilim alanına nasıl katkıda bulunabilir? Bu bağlamda varılabilecek en temel sonuç, çevirilerden hareketle yapılan biçembilim çalışmalarının ışığında, çevirilerin yapıldı̆̆ı dönemde erek yazın dizgesinin durumuna, okurların muhtemel beklentilerine ve olası çeviri normlarına ilişkin bazı bilgilerin elde edilebileceğidir. $\mathrm{Bu}$ nedenle, çeviribilim çalışmaları ile biçembilim çalışmalarının bütünleştirilmesi, toplumsal bağlama ilişkin veriler elde edilmesi açışısından önem taşımaktadır.

\section{Kaynakça}

Adamson, S. (1998). Literary language. S. Romaine (Ed.), The Cambridge History of the English Language (589-692). Cambridge: Cambridge University Press.

Berman, A. (1990). La retraduction comme espace de traduction. Palimpsestes, 13, 1-7.

Boase-Beier, J. (2003). Mind Style Translated. Style, 37(3), 253-265.

Boase-Beier, J. (2014). Stylistic Approaches to Translation. Manchester: St. Jerome.

Bradbury M. (1973). Possibilities: Essays on the State of the Novel. London: Oxford University Press.

Bockting, I. (1994). Mind-style as an Interdisciplinary approach to characterisation. Language and Literature, 3(3), 157-174.

Chatman, S. (1978). Story and Discourse: Narrative Structure in Fiction and Film. Ithaca, NY: Cornell University Press

Daniel, J. S. (1997). William Faulkner: The Making of a Modernist. Chapel Hill: U. of North Carolina Press.

Deane-Cox, S. (2014). Retranslation: Translation, literature and reinterpretation. London: Bloomsbury.

De Quincey, T. (1993). İngiliz Posta Arabası (M. H. Doğan, Çev.). İstanbul: YKY.

Dobrow, G. W. (2001). Figures of Play: Greek drama and metafictional poetics. Oxford: Oxford University Press.

Ecevit, Y. (2001). Türk Romanında Postmodern Açllımlar. İstanbul: İletişim. 
Erkazancı Durmuş, H. (2019). William Faulkner'ın The Sound and The Fury Eserinde Düşünce Biçeminin Türkçeye Aktarılması. Çeviribilim ve Uygulamaları Dergisi, (25), 51-70.

Faulkner, W. (1987). The Sound and the Fury. New York: Vintage.

Faulkner, W. (1965). Ses ve Öfke (R. Güran, Çev.). Istanbul: Remzi.

Fowler, R. (1977). Linguistics and the Novel. Bungay: Methuen and Co.

Fowler, R. (1996). Linguistic Criticism. Oxford: Oxford University Press.

Gümüs, S. (2015). Modernizm ve Postmodernizm: Edebiyatın Dünü ve Yarmı. İstanbul: Can.

İnceoglu, S. (2012). Varlığın Karşı Konulamaz Kayboluşu: Yanardağın Altında(Ki) Ölüm. Litera, 23 (2), 11-22.

Joyce, J. (1992). Ulysses. London: Penguin Books.

Joyce, J. (1996). Ulysses (N. Erkmen, Çev.). İstanbul: Yapı Kredi.

Joyce, J. (2011). The Portrait of The Artist As A Young Man. New Jersey: Dover Publications.

Joyce, J. (2016) Sanatçının Bir Genç Adam Olarak Portresi (M. Belge, Çev.). İstanbul: İletişim.

Langacker, R. (1987). Foundations of Cognitive Grammar: Volume I Theoretical Prerequisites. Stanford, CA: Stanford University Press

Leech, G \& Short, M. (1981). Style in Fiction. Harlow: Pearson Education

Mcintyre, D. (2006). Point of View in Plays. Amsterdam/Philadelphia, PA: John Benjamins.

Lowry, M. (1974). Yanardă̆ (A. Üstel, Çev.). İstanbul: Hürriyet.

Lowry, M. (1989). Yanardağın Altında (S. Fişek, Çev.). İstanbul: Can.

Lowry, M. (2012). Under the Volcano. New York: Harper Perennial Modern Classics.

Margolin, U. (2003). Cognitive Science, the Thinking Mind, and Literary Narrative. D. Herman (Yay. Haz.), Narrative Theory and the Cognitive Sciences içinde, (271-294). Stanford: Stanford University Centre.

Nuttall, L. (2018). Mind Style and Cognitive Grammar. London: Bloomsbury

Riquelme, J. (1983). Teller and Tale in Joyce's Fiction: Oscillating Perspectives. Baltimore, MD: Johns Hopkins University Press.

Robinson, K. (2018). Not altogether darkness: Drunkenness in Lowry's Under the Volcano. The Explicator. https://doi.org/10.1080/00144940.2018.1453773 (accessed 12 November 2018)

Rundquist, E. (2014). How is Mrs Ramsay thinking? The semantic effects of consciousness presentation categories within the free indirect style. Language and Literature, 23(2), 159-173.

Rundquist, E. (2020). The Cognitive Grammar of drunkenness: Consciousness representation in Under the Volcano. Language and Literature, 29(1), 39-56.

Semino, E. (2002). A cognitive stylistic approach to mind style in narrative fiction. E. Semino \& J. Culpeper (Yay. Haz.), Cognitive Stylistics: Language and Cognition in Text Analysis içinde, (95122). Amsterdam: John Benjamins.

Semino, E. (2007). Mind style 25 years on. Style, 41(2), 153-203

Semino, E. \& Culpeper, J. (2002). Cognitive Stylistics: Language and Cognition in Text Analysis. Amsterdam: John. Benjamins.

Semino, E. \& Swindlehurst, K. (1996). Metaphor and mind style in Ken Kesey's One Flew over the Cuckoo's Nest. Style, 30(1), 143-166.

Shakespeare, W. (1981). Macbeth (S. Eyüboğlu). İstanbul: Remzi.

Shakespeare, W. (1994). Hamlet. London: Penguin. 
Shakespeare, W. (1999). Hamlet (B. Bozkurt, Çev.). İstanbul: Remzi.

Shakespeare, W. (2015). Macbeth. London: Arden.

Stockwell, P. (2002). Cognitive Poetics: An Introduction. London: Routledge

Vandamme, C. (2016). Lowry and Jakobson: Spatial Pyrotechnics and Poetic Writing. Richard J. lane \& M. Mota (Yay. Haz.), Under the Volcano Malcolm Lowry’s Poetics of Space içinde, (45-60).

van Peer, W. (1993). Typographic Foregrounding. Language and Literature, 2(1), 49-61. 